Primljen / Received: 15.9.2011

Ispravljen / Corrected: 24.5.2012.

Prihvaćen / Accepted: 30.5.2012.

Dostupno online / Available online: 25.6.2012.

\section{Orientation toward sustainable water supply}

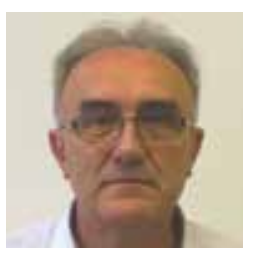

Prof. Živko Vuković, PhD. CE University of Zagreb Faculty of Civil Engineering vukovic@grad.hr

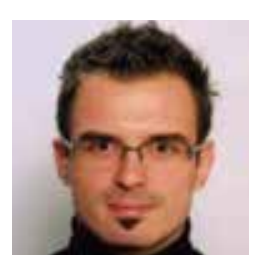

Ivan Halkijević, B.Sc. CE

University of Zagreb

Faculty of Civil Engineering

halkijevic@grad.hr

\section{Živko Vuković, Ivan Halkijević}

\section{Orientation toward sustainable water supply}

The current global lack of sustainability in water supply, as caused by excessive use of drinking water reserves, and water quality deterioration due to various intensive uses of water, is presented in the paper. An overview of present-day research and advancements that contribute to gradual and durable orientation toward sustainable water supply is given. The recycling and reuse of water in order to enable an efficient increase in available quantities of water is analyzed. Latest discoveries in the field of nanotechnology, as related to water treatment with minimum environmental impact, are presented.

\section{Key words:}

sustainable water supply, increase in water supply, reduction in water consumption, recycled water, reused water

Pregledni rad

\section{Živko Vuković, Ivan Halkijević}

\section{Usmjerenost prema održivoj vodoopskrbi}

Prikazano je današnje globalno stanje neodrživosti vodoopskrbe uzrokovano prekomjernom potrošnjom zaliha pitke vode i pogoršanjem kvalitete vode zbog mnogostrukih načina njezine intenzivne upotrebe. Sustavno se izlažu aktualna znanstvena istraživanja i spoznaje kojima se pridonosi postupnoj i trajnoj usmjerenosti prema održivoj vodoopskrbi te upozorava na potrebu integralnog gospodarenja vodoopskrbnim sustavima. Za učinkovito povećanje vodoopskrbnih količina analizira se recikliranje i ponovna upotreba vode. Navode se i najnovija nanotehnološka otkrića u području tretmana voda s minimalnim utjecajima na okoliš.

\section{Ključne riječi:}

održiva vodoopskrba, povećanje vodoopskrbe, smanjenje potrošnje vode, reciklirana voda, ponovno upotrijebljena voda

Übersichtsarbeit

Živko Vuković, Ivan Halkijević

\section{Orientierung in Richtung Nachhaltigkeit in der Wasserversorgung}

In der Arbeit wurde auf den heutigen globalen Zustand der fehlenden Nachhaltigkeit in der Wasserversorgung aufgezeigt, der durch einen übermäßigen Trinkwasserverbrauch und eine Verschlechterung der Wasserqualitätwegen der vielfältigen, intensiven Verwendung entstanden ist. Es wurde eine Übersicht der aktuellen wissenschaftlichen Forschungen und Erkenntnisse gegeben, die einer schrittweisen und dauerhaften Orientierung in Richtung nachhaltiger Wasserversorgung beitragen. Es wird die Wiederverwertung und Wiederverwendung von Wasser zum Zwecke einer effizienten Erhöhung von Wasserversorgungsmengen analysiert. Es werden neueste nanotechnologische Entdeckungen in dem Bereich der Wasserbehandlung mit minimalem Einfluss auf die Umwelt angeführt. 


\section{Introduction}

One of the greatest challenges of the $21^{\text {st }}$ century is to ensure better living conditions for all people of the world, and to reduce at the same time the impact of human activities (anthropogenic influences) on natural ecosystems and global environment [1].

As water is of fundamental significance for every human being, and as it is in many instances actually irreplaceable, one of high-priority activities in the realization of this noble objective is to ensure accessibility and sufficient quantities of drinking water, in order to satisfy both present needs and the needs of generations to come. However, very modest and limited steps have so far been made on the global level to solve growing problems of water supply and environmental protection in general, especially in less privileged countries. In fact, the world is dealing with new problems and challenges in the same way as before [2].

Although water is a renewable natural resource, due to disruption of hydrological cycle, we now find ourselves in the situation where natural drinking water reserves are being depleted at a much faster rate than they a naturally replenished. Furthermore, due to limited availably of water and its varied and intensive use, the quality of this resource deteriorates to such an extent that, in some instances, it can no longer be used for any purpose. An effective increase in the quality of such water is on the one side highly expensive (cost of energy, technology, and final disposal of waste) while, on the other side, it causes significant pressures on environment with the resulting negative influences [3].

This is why we now have on the global level 1.2 billion of people with no access to drinking water, 2.6 million of people drink inadequate water, and millions of people, out of which 4000 are children, die each day due to diseases transferred by such water [4]. It is currently estimated that about 4 billion of people living on the Earth, or every second inhabitant, will be lacking drinkable water by 2025 when the world's population is expected to reach 8 billion [5].

The likely increase in water consumption due to expected increase in the number of inhabitants will lead to additional pressures on water resources. This is why present day practices in water management, and hence in water supply, can rightly be considered unsustainable. To continue with current ways would mean unreasonable squandering of natural water resources, which would leave us with nothing to offer to our descendants [6].

Therefore, the objective of this paper is to present current global situation in the sphere of water supply, and to analyze reasons for its unsustainability, as well as to give an overview of present day research aimed at gradual resolution of water supply problems, with permanent orientation toward sustainable water supply.

\section{Concept of sustainability}

The universal concept of environmental sustainability, which is defined as the capability of meeting our current needs for natural resources without endangering capabilities of future generations to meet their own needs [2], is presently offered as solution that is most likely to satisfy current and future drinking water requirements. In other words, the environmental sustainability is the capability of humans to manage natural resources for an unlimited period of time without imposing pressures on natural systems, which enable preservation of life on the Earth. This implies preservation of such quantities of good-quality natural resources that are sufficient not only for meeting current needs, but also for ensuring future economic development and an undisturbed and environment-friendly use of such resources by future generations.

Sustainability criteria can be met over a long (infinite) period of time by creating a balance between three closely interwoven components: balanced and stable economic development that does not cause further degradation of natural environment (environmental component); creation of society characterized by solidarity between generations in which differences are respected in the framework of democratic values (social component); preservation of all environmental components as a natural asset upon which both present and future generations are dependent (environmental component) [7, 8] (Figure 1.). Basically, the concept of sustainability implies solidarity of all stakeholders that take part in the natural resources management processes. The realization of this concept will undoubtedly be a long lasting process, which is bound to strongly influence all layers of the society.

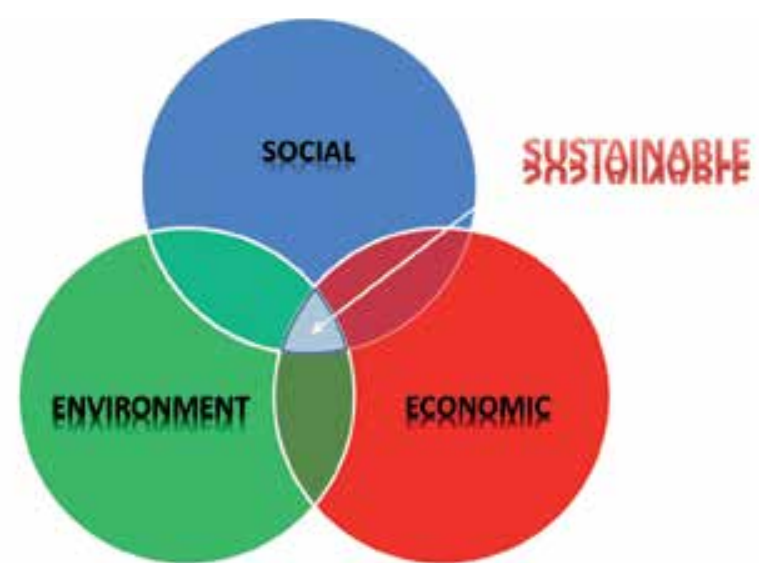

Figure 1. Sustainability components

In addition, according to the International Union for Conservation of Nature, the sustainability is improving the quality of human life while living within the carrying capacity of supporting eco-systems [9]. 
The carrying capacity of support systems may be described as allowable burdening of environment with a maximum number of users, combined with various activities, use of natural resources and waste disposal, which can be supported during an unlimited period of time by a natural or artificial environment, without endangering its stability, without reducing its natural values (degradation), and without harmful effects on human health.

The global stability of our environment is nowadays greatly endangered by the abrupt and excessive increase in the world population, with the corresponding anthropogenic influences. The Earth, regarded as a system, is therefore threatened by destabilization, with significant or even catastrophic consequences. This thesis is increasingly accepted by researchers who define the Earth's system as a set of related and interactive physical, chemical, biological and socioeconomic processes that control the global state of the environment. A new conceptual framework - planetary boundaries for defining safe scope of human action and the functioning of the Earth's system - has been proposed (Figure 2 .and Table 1.) [10].

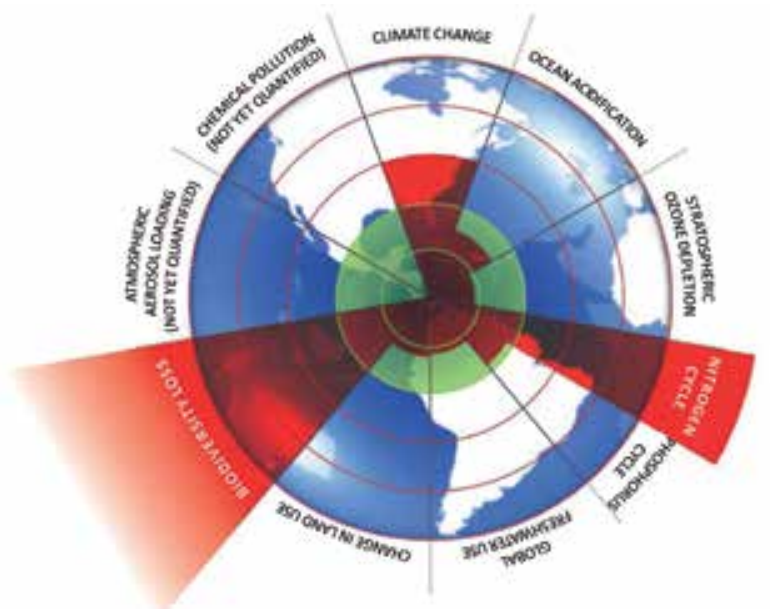

Figure 2. Planetary boundaries

Proposed planetary boundaries are related to nine areas on which the global sustainability is based: climate change, ocean (sea) acidification, stratospheric ozone depletion, nitrogen and phosphorus cycles, global freshwater use, change in land use,

Table 1. Planetary boundaries with proposed boundary and current values of the control variables

\begin{tabular}{|c|c|c|c|c|c|}
\hline $\begin{array}{l}\text { Ord. } \\
\text { Num. }\end{array}$ & $\begin{array}{l}\text { Earth-system } \\
\text { process }\end{array}$ & Parameters & $\begin{array}{l}\text { Proposed } \\
\text { boundary }\end{array}$ & $\begin{array}{l}\text { Current } \\
\text { status }\end{array}$ & $\begin{array}{c}\text { Preindustrial } \\
\text { value }\end{array}$ \\
\hline 1 & Climate change & $\begin{array}{l}\text { (i) Atmospheric carbon dioxide concentration, [ppmv] } \\
\text { (ii) Change in radiative forcing, }\left[\mathrm{W} / \mathrm{m}^{2}\right]\end{array}$ & $\begin{array}{c}350 \\
1\end{array}$ & $\begin{array}{l}387 \\
1.5\end{array}$ & $\begin{array}{c}280 \\
0\end{array}$ \\
\hline 2 & $\begin{array}{l}\text { Rate of biodiversity } \\
\text { loss }\end{array}$ & $\begin{array}{c}\text { Extinction rate, } \\
\text { [number of species } / 10^{6} \text { species per year] }\end{array}$ & 10 & $>100$ & $0,1-1$ \\
\hline 3 & $\begin{array}{l}\text { (i) Nitrogen cycle } \\
\text { (ii) Phosphorus cycle }\end{array}$ & 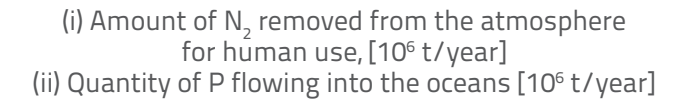 & $\begin{array}{l}35 \\
11\end{array}$ & $\begin{array}{c}121 \\
8,5-9,5\end{array}$ & $\begin{array}{l}0 \\
\sim 1\end{array}$ \\
\hline 4 & $\begin{array}{l}\text { Stratospheric ozone } \\
\text { depletion }\end{array}$ & Concentration of ozone, [Dobson unit] & 276 & 283 & 290 \\
\hline 5 & Ocean acidification & $\begin{array}{c}\text { Global mean saturation state of aragonite } \\
\text { in surface sea water }\end{array}$ & 2,75 & 2,90 & 3,44 \\
\hline 6 & $\begin{array}{l}\text { Global freshwater } \\
\text { use }\end{array}$ & Consumption of freshwater by humans, [km³/godina] & 4000 & 2600 & 415 \\
\hline 7 & Changes in land use & Percentage of global land cover converted to cropland & 15 & 11,7 & niska \\
\hline 8 & $\begin{array}{l}\text { Atmospheric aerosol } \\
\text { loading }\end{array}$ & $\begin{array}{c}\text { Overall particulate concentration in the atmosphere, on } \\
\text { a regional basis }\end{array}$ & \multicolumn{3}{|c|}{ To be determined } \\
\hline 9 & Chemical pollution & $\begin{array}{c}\text { Amount emitted to, or concentration of persistent } \\
\text { organic pollutant, plastics, endocrine disrupters, heavy } \\
\text { metals, nuclear waste, etc. in the global environment, } \\
\text { or the effects on ecosystem and functioning of Earth } \\
\text { system thereof }\end{array}$ & \multicolumn{3}{|c|}{ To be determined } \\
\hline
\end{tabular}


rate of biodiversity loss, atmospheric aerosol loading, and chemical pollution.

To avoid catastrophic consequences for our environment, the human behaviour and the use of natural resources must be kept within safe ranges of the proposed planetary boundaries (green area in Figure 2.). However, humans have already exceeded three of these nine boundaries: climate change, rate of biodiversity loss, and input of nitrogen into the biosphere. It should however be noted that extreme caution should be exercised careful when defining the extent of climate change. In fact, the present day science is still seeking the answer to the question of whether climate occurrences witnessed over the past several decades are a sign of climate change, or can simply be regarded as usual variations of climate [11].

As to the existing freshwater reserves, the global situation is still not considered catastrophic because about $2600\left[\mathrm{~km}^{3}\right]$ of available $4000\left[\mathrm{~km}^{3}\right]$ are currently used each year. However, the real issue is the distribution of existing freshwater quantities in space and time, and hence of their actual availability.

\section{Sustainable water supply}

Sustainable water supply is the water supply meeting our present and future requirements for sufficient quantities of good-quality (drinkable) water without endangering natural hydrologic cycle and water-dependent ecosystems. The respect of this concept ensures continued human progress and healthy environment for future generations [6],12].

Hence, the aims are set high and many changes to the better are needed for their realization, e.g. in population policy, industry (manufacturing), agriculture, economy, use of energy, etc. In addition, the ethical aspect of sustainability also calls for fundamental change in the way humans think about the water and water supply. Instead of constantly looking for new water resources that will enable realization of their future (consumption) wishes, people have to find the ways to meet current and future human and ecological needs using water that is presently at our disposal [6]. This is a significant shift in the way of thinking that requires an in-depth analysis and decision making at the highest national and international levels.

This approach does not mean that the quality of human life must be lowered. On the contrary, better living conditions will thus be provided. The achievement of a sustainable water supply is greatly dependent on finding solutions that will be able to meet numerous challenges the mankind is faced with today.

\subsection{Current water supply situation}

The main problem with the present day water supply is its unsustainability in practically all segments [13]. Many sources of potable water are polluted and are fully or excessively used, some of them irreversibly, and those in coastal areas are additionally exposed to saline water penetration (salination) [14].

Former approach to meeting drinking water demand under conditions of demographic expansion, strong growth of industrial production, and greatly increased food production (irrigation), was based on continuous search for new sources of water, and construction of big water supply systems, often on regional and even higher levels. Such approach has resulted in the planning, design, construction, use, and maintenance of highly expensive systems characterized by large-capacity structures: intake structures, pumping stations, water purification plants, water tanks, and hundreds (and even thousands) $\mathrm{km}$ long large-diameter pipelines [15]. Such systems are highly intensive with respect to space, infrastructure, energy, operation, chemical impacts, and technology. They are also highly detrimental to natural environment [16].

In addition, former approach to water as an exclusive public resource is nowadays fully unacceptable. Water is not only a natural and public resource but an economic asset as well, which is mostly due to economic and financial costs related to the supply and preservation of water, shortages and/or limited availability of water, and privatization of the public water supply sector [15]. An additional fact in support of the need for changing our attitude toward water concerns considerable water losses in water supply systems, primarily because of lack of maintenance. These losses, most due to pipeline breakdown or leakage at pipe connections, often exceed 50 percent of water transported by such systems. On the global level, the economic price of water lost in this way is estimated at about US\$ 14 billion annually [17].

Furthermore, water-related needs of various living species and natural eco-systems are often neglected in our attempts to secure sufficient quantities of clean water for various human needs. Environmental consequences of such actions are tragical, as water quantities that can be used for human consumptions, compared to overall quantities of water, should be limited. This limitation is defined by water demand of eco-systems. If this limitation is exceeded in the sense of full or excessive use of water for human consumption only, various species will be reduced in numbers or fully lost, i.e. this will result in the reduction of biological diversity, and so the possibility of using these species for instance in agriculture (food production), medicine (production of drugs), construction (production of construction materials), etc., will be irreversibly lost. In conclusion, sustainable use of water implies simultaneous definition of compatibilities between human needs for water and the needs of ecosystems, in order to ensure sustainability of mankind and ecosystems alike. Also, it is now obvious that the sustainability concept can not be realized without sustainable cities (urban communities) where sustainable water supply is certainly one of main concerns $[13,16]$. Among other things, the urbanization brings 
an increased and concentrated consumption of agricultural produce, energy, and raw materials - including water and, as a consequence of this consumption, we have emission of air pollutants, waste heat and water pollutants, and creation of solid waste, which eventually results in pollution of our environment [19].

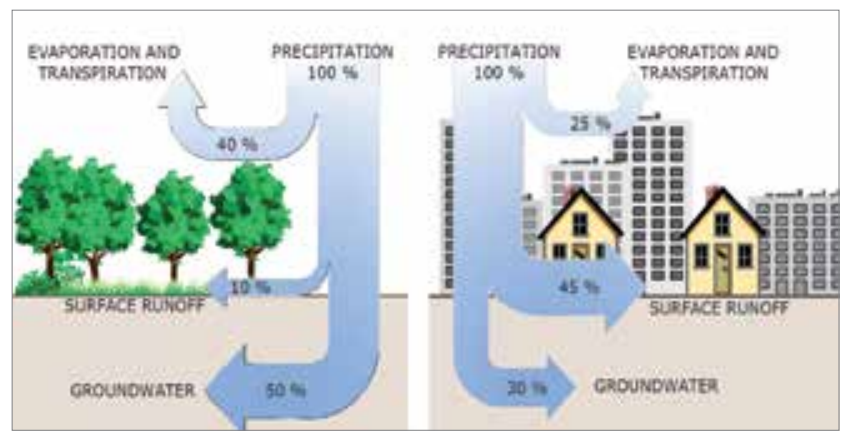

Figure 3. Average values of hydrological parameters a) pre-urban; (b) urban

One of significant effects of urbanization is the change of natural hydrological cycle [2] (Figure 3.).

Depending on the construction method used, impermeable surfaces built in big cities (building roofs, squares, roadways) may take up as many as 60 percent of the total area occupied by the city. In such circumstances, great quantities of rainwater falling in urban areas do not reach the underground but are collected (concentrated) and carried out of urban communities as a category of waste water. This activity contributes to depletion of dynamic reserves of ground water, i.e. to impoverishment of aquifers that are needed for the supply of water to urban agglomerations.

That is why comprehensive, rapid and efficient actions and changes are needed to solve the above-mentioned problems, and to trace the path toward a sustainable water supply.

\subsection{Achievement of sustainable water supply}

The present day approach to the resolution of water supply problems can generally be divided into two categories [13], $[20,21]$ :

a) increase of water supply,

b) reduction of water demand.

\subsubsection{Increase of water supply}

When considering possibilities for increase in water supply, it is first of all necessary to examine former attitudes to water supply, and to environmental protection in general. The initial or "simplest" and in many cases "cheapest" solution, appropriate to the time of abundance in water and lack of care about environment and water, is shown in Figure 4. This water supply solution is possible under assumption that water source capacities meet water needs of humans and $Q_{p} \approx Q_{i} \quad Q_{0}<Q_{p}$

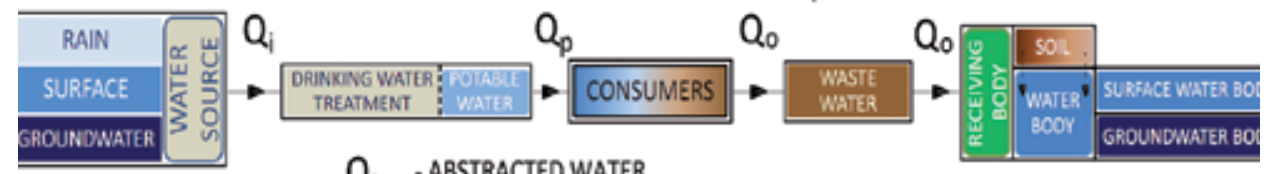

$Q_{i}$ - ABSTRACTED WATER

$Q_{p}$ - POTABLE WATER

$Q_{0}$ - WASTE WATER

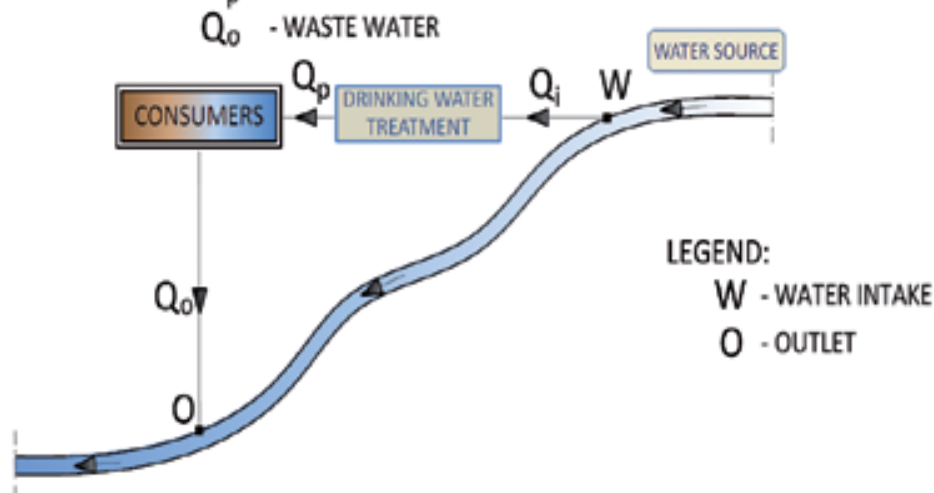

Figure 4. Linear systems without waste water treatment
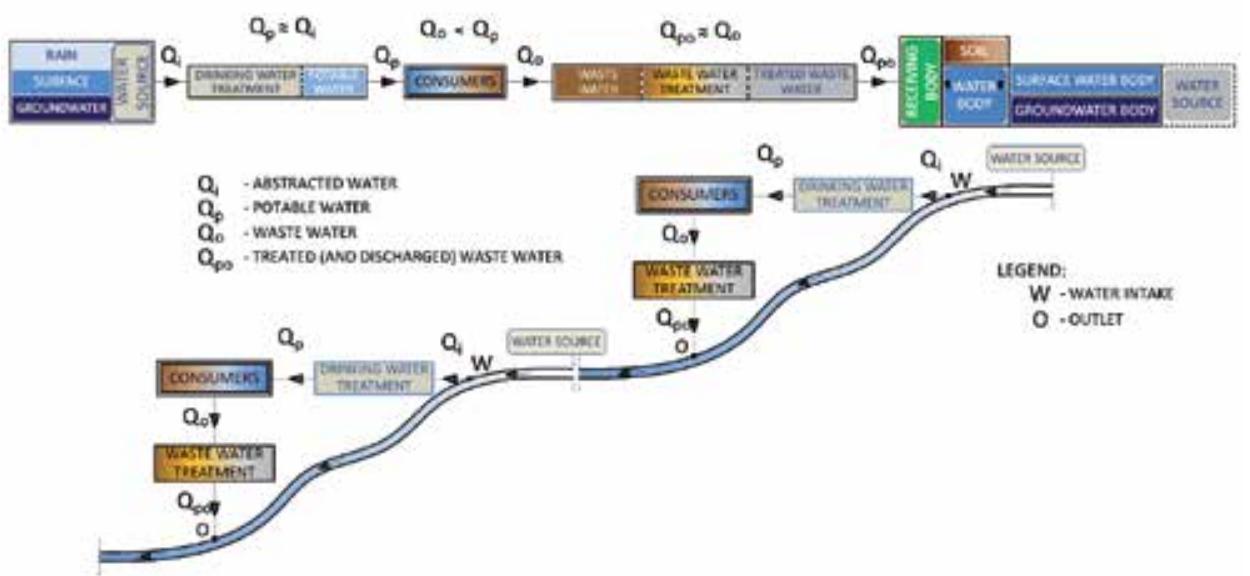

Figure 5. Linear system with waste water treatment 
ecosystems alike. These are linear systems or systems with one-time use of water.

Here, quantities of water are collected at the source and, after quality improvement (conditioning), the water is distributed to consumers. After one-time use the water, now categorized as waste water, is collected and then released into the environment, or a receiving body of water, without any treatment.

Depending on waste water properties, waste water to receiving water ratio, and auto-purification capabilities of receiving water, the impact on receiving bodies of water may be either low or more pronounced. Thus the possibility of using the same receiving water for water supply downstream from the place where waste water has been released, becomes highly questionable, and in many cases even impossible. However, these systems are still quite often used, especially in undeveloped countries.

Due to increase in community awareness about the need to protect natural environment, waste water is treated before being released into the final place of discharge (Figure 5.), and the waste water impact on environment is inversely proportional to the water purification level. These systems also imply that the quantities of water at water source are sufficient for meeting all water requirements, and so these systems are also considered to be systems with one-time use of water.

In case of higher levels of waste water treatment and/or higher receiving water and effluent ratio, and more pronounced self-purification capabilities of receiving water, the same receiving water can be used as a water source to the downstream of the place where waste water has been released.

If water quantity in the water sources does not meet water requirements (either constantly or in dry season), then the water supply quantities can be increased by realizing non-linear or circular systems, or multiple use of water systems. These systems are characterized by recycling or reuse of water $[2$, 22].

The recycled water is a (highly) treated waste water, i.e. water that has passed through multiple levels of treatment, including possible purification to the drinking water standard, which makes in safe for beneficial uses.

The reused water is (generally) an untreated waste water that is directly used for a purpose not requiring use of drinking water. In case of domestic effluents, these are the so called gray waters, i.e. waters used for preparation of food, washing dishes and clothes, and for personal hygiene and apartment cleaning, which can directly be used for garden and house plot watering, car washing and toilet flushing. In industry, this water is mostly used for cooling.

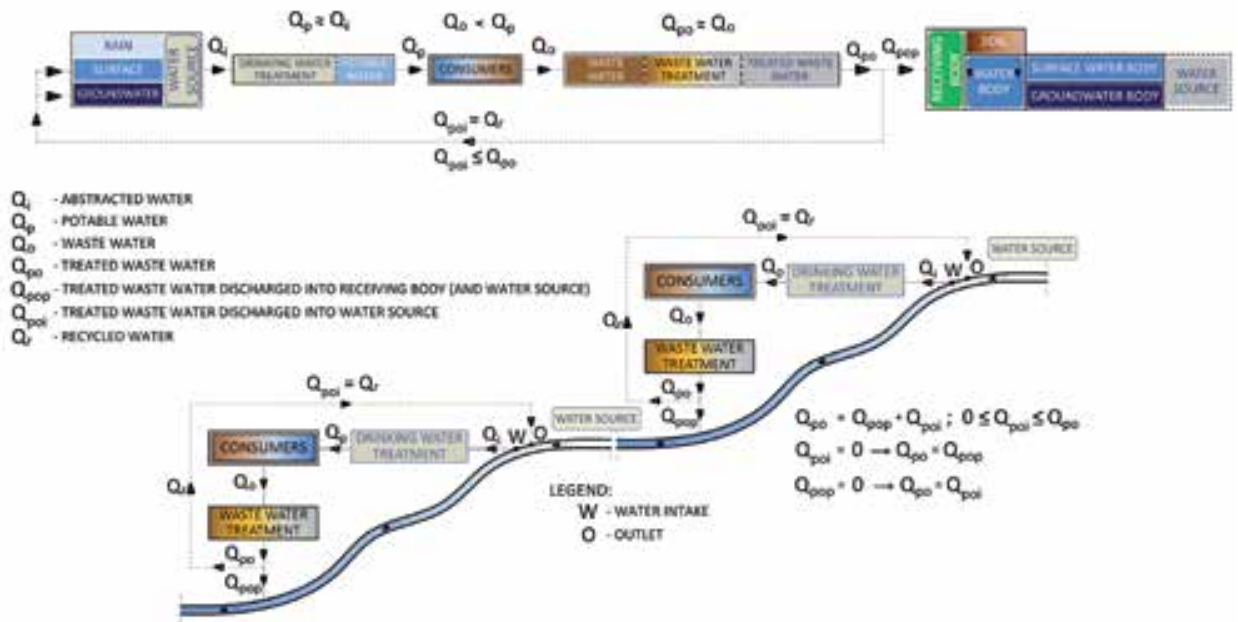

Figure 6. Circulation system with indirect use of recycled water
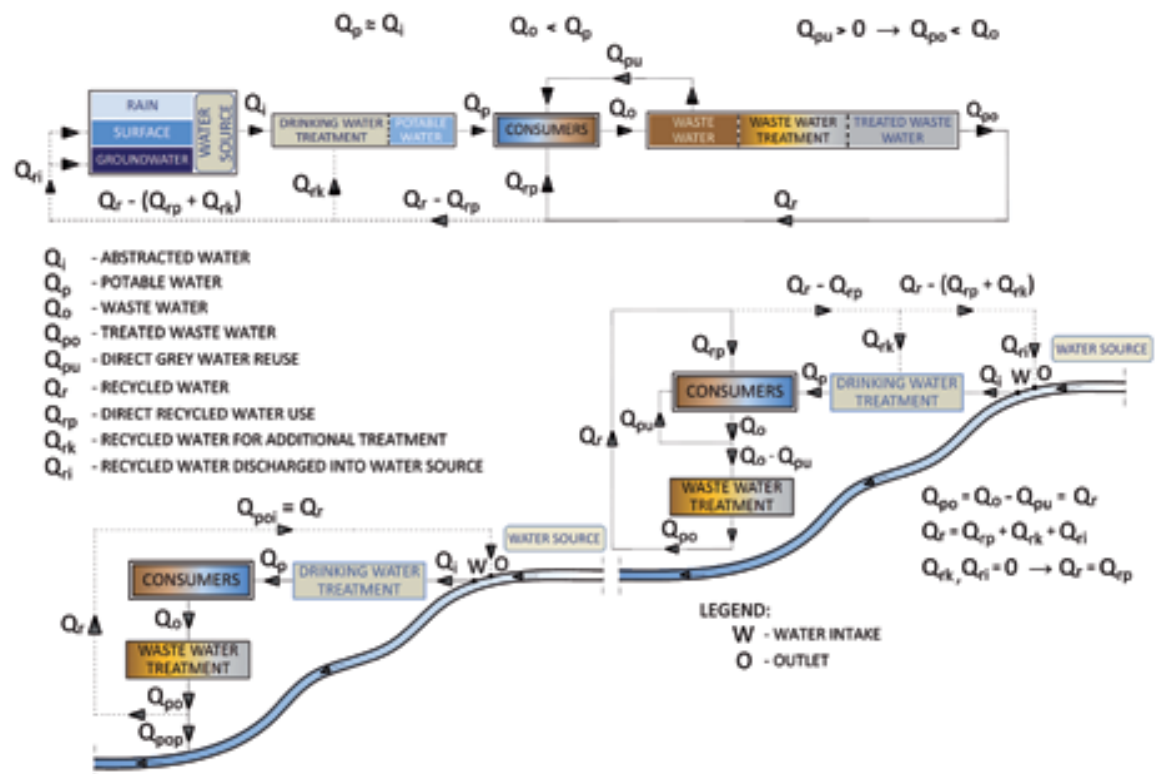

Figure 7. Circulation system with direct and indirect use of recycled water and with direct reuse of water 
In fact, most of the water used in water supply is returned into environment, i.e. into the hydrological cycle, as waste water. About 30 to 40 percent of water is returned from agricultural surfaces and livestock farms, about 80 to 90 percent from the industry, and about 75 to 85 percent from households [14]. Therefore, a highly efficient way to increase water supply quantities, otherwise inaccessible from the natural water cycle, is the recycling and reuse of waste water. This is, in addition to ensuring continuous water supply, one of the most efficient ways for protecting our environment [23].

Figure 6 shows the circulation cycle, with release of recycled water to the upstream of the water supply point, which is why this system is called an indirect system [21].

In case of highly treated waste water, the combination is possible with mostly direct (consumers) and less indirect use of recycled water (conditioning + water well recharge). The system may also be characterized by direct reuse of waste water (Figure 7.). Because of high level of water treatment required, these systems are very expensive, especially for bigger cities, where water consumption is high, and so they are very seldom used in practice.

In the above schematics of the system (Figures 4. to 7.) the atmospheric well points are also cited as a water well type. At atmospheric well points, the water primarily originates from rain. They are appropriate for individual water supply, and for smaller communities.

Gathering rain water for instance from roofs is an additional water source enabling complete individual water supply or considerable water savings, as this water can be - for many household uses, from garden and house plot watering, car washing, and toilet flushing, to the use of advanced models with water filtration and disinfection, which are directly linked to the existing water supply system of the house, which is in turn connected to the public water supply system. In such models, the investment can be reimbursed within a five year period, or even faster [24].

\subsubsection{Reduction of water demand}

In order to analyse possibilities for reducing water demand, the distribution of water use by point of consumption, in households of three highly developed countries [2], is presented in Figure 8. It can be seen from this figure that the water is dominantly used in toilets and bathrooms (about fifty percent).

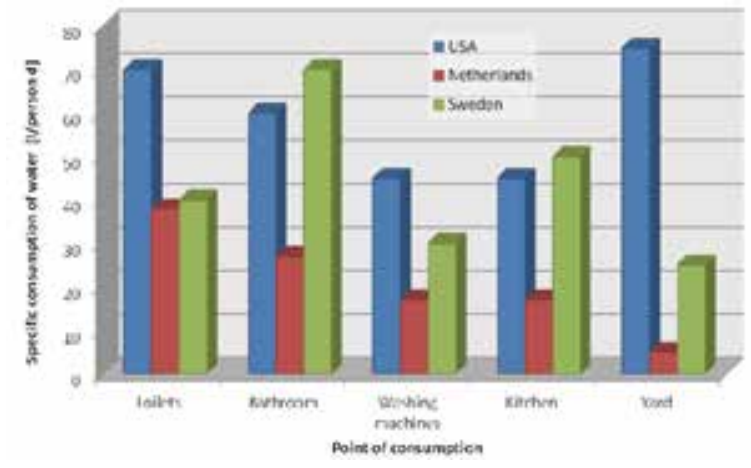

Figure 8. Water demand in households, example of three highly developed countries

Average proportions of water consumption, with appropriate quantities of waste water in households by point of consumption, are presented in Table 2., together with calculation of other consumption parameters for an assumed four-member household. It can be seen that the proportion of gray waters in the assumed consumption amounts to 50 percent, i.e. $2 / 3$ of the total quantity of waste water generated in the household (gray waters + black waters $=400+240=640$ (I/d)

It would therefore be reasonable to directly reuse the gray water for e.g. garden and plot watering, car washing, and toilet flushing. Up to 50 percent of drinking water can be saved in households by reuse of gray waters for toilet flushing, with the return of investment in 3 to 5 years [24].

Biological and nontoxic washing and cleaning substances should be used in households to provide for adequate sanitary safety of gray water. Otherwise, a certain (lower) level of gray

Table 2. Water and gray water consumption parameters for a household, by point of consumption

\begin{tabular}{|c|c|c|c|c|c|}
\hline $\begin{array}{l}\text { Point } \\
\text { of consumption }\end{array}$ & $\begin{array}{l}\text { Specific consump- } \\
\text { tion of water } \\
\text { [I/person d] }\end{array}$ & $\begin{array}{c}\text { Proportion in spe- } \\
\text { cific consumpti } \\
\text { on of water } \\
{[\%]}\end{array}$ & $\begin{array}{c}\text { Water consumption } \\
\text { [I/person d] }\end{array}$ & $\begin{array}{l}\text { Water consumption } \\
\text { for a four-member } \\
\text { household } \\
\text { [I/d] }\end{array}$ & $\begin{array}{c}\text { Quantity of gray } \\
\text { water for a four- } \\
\text { member household } \\
\text { [l/d] }\end{array}$ \\
\hline Toilets & \multirow{5}{*}{200} & 30 & 60 & 240 & - \\
\hline Bathroom & & 25 & 50 & 200 & 200 \\
\hline Washing machines & & 15 & 30 & 120 & 120 \\
\hline Kitchen & & 10 & 20 & 80 & 80 \\
\hline \multirow[t]{2}{*}{ Yard } & & 20 & 40 & 160 & - \\
\hline & Ukupno: & 100 & 200 & 800 & $400(50 \%)$ \\
\hline
\end{tabular}


water purification, in most cases filtering and disinfection, also resulting in removal of bacteria and organic substances, is needed. In case gray water is used for watering, the soil must be tested regularly for nutrient and chemical composition [24]. Water savings can be made at all devices (water outlet points) used in our households. Thus for instance [24]:

- Traditional toilets use up to 12 litres of water per flush, while low flush-toilets use less than 4 litres. Water consumption can additionally be reduced by using the "stop" option on the cistern.

- Showers use about $20 \mathrm{l} / \mathrm{min}$ of water at a usual water pressure ( 3 bars). If low flow (massage) shower heads are used, less than $10 \mathrm{l} / \mathrm{min}$ are consumed at the same pressure;

- Water efficient dishwashers use 16 I of water per load compared for 40 litres for hand washing dishes.

- Older types of washing machines use more than 100 litres of water per load, while high efficiency models use less than 50 litres;

- Conventional twist taps use around 4 litres of water per hand wash, while sensor taps can reduce this to 2 litres or less.

Thus, significant direct savings in water and power can be made if modern energy-efficient appliances and devices are used. In addition, continuous leakage of water at water fixtures can be eliminated by proper maintenance of household water fixtures (taps, valves, WC cisterns). This leakage can amount to several tens of litres per day per discharge point, and per place of breakdown or leakage, depending on the extent of fixture defect. Using the same analogy, water savings can also be made in industry by introducing modern "energy-efficient" technological processes, and by proper maintenance of industrial watersupply infrastructure.

\section{Integrated water management}

To attain sustainable water supply objectives, an integrated management of water supply systems should be ensured (Figure 9).

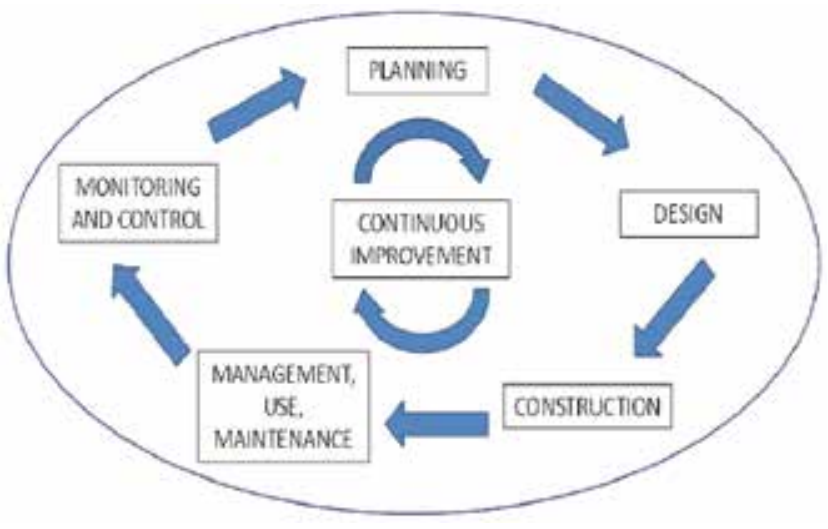

Figure 9. Integrated management of water-supply systems
The management process [25] is made of five cyclic activities (phases) which begin by water systems planning, and continue by their design, construction and operation, use and maintenance, and monitoring/control of realization of objectives, so as to identify possibilities for improvement and give us input for the new cycle, which begins by planning water supply systems for future periods.

(1) Planning, as the first step of the process, is of enormous significance for the overall success of the water system management. It is greatly dependant on the quality and systemization of background data on water resources, users, economic activities, etc., i.e. on the data base established for this activity [26]. An integrated or all-comprising planning is needed to harmonize different interests of various stakeholders interested in an area where the quality of environment is protected and preserved.

Such an integrated planning enables harmonization of multiple and overlapping interests of these stakeholders in a rational manner, with proper preservation and protection of environment, while at the same time ensuring realization of the highest level of socioeconomic benefit for the present generation, and for the generations to come. Therefore, the planning based on a sectorial approach, which does not take into account an overall impact on natural riches, can not be considered as rational [3].

(2) At the phase in which water systems are designed, various design possibilities should be explored to devise water supply systems that fully contribute to the preservation of natural eco-systems. In this respect, designers should not hesitate to develop facilities that are apparently more costly but are highly favourable in the long run from the standpoint of environment protection and preservation costs.

Furthermore, the use of secondary raw materials and local building materials should be encouraged, with the reduced use of primary raw materials (natural resources). Production of waste should be reduced to necessary minimum, and construction materials that may prove harmful to environment should be avoided. Thus materials presenting no harm to human health and natural environment should be used, and energy savings should be made by adopting energy efficient materials and technological processes [27].

(3) At the phase in which water supply systems are actually built, care must be taken to ensure that construction technologies used do not contribute to the deterioration of environment, both in the local community and the wider area. A special attention should be paid to preserving the quality of air, soil and water (ground water in particular).

The situation in natural habitats changes, either directly or indirectly, during construction of water supply facilities. This also brings about long-term changes in the eco-systems (anthropogenic successions).

Some pollution during construction of water supply systems may also be caused by the use of construction machinery powered by liquid fuel, by noise, and by leakage of fuel and lubricants. 
The construction waste, which mostly belongs to the category of nonhazardous waste, should be adequately disposed (treated and/or carried to the final place of disposal) in a way that is not detrimental to human health, using procedures not harmful to the environment or presenting the least possible harm to environment.

(4) Good management, operation and maintenance of water supply infrastructure is of crucial significance for successful implementation of a sustainable water supply.

In practice, greatest defects and failures, causing negative economic effects, and unsustainability in water supply, occur at the very phase of water supply management. One of such defects is the already mentioned loss of water (water leakage), which is in fact one of fundamental indicators pointing to unsustainability of a water supply system. In addition, significant quantities of energy, materials, natural resources (often non-renewable ones), and space, are used in order to obtain drinking water, which contributes in the end to the degradation of all components of our environment (air, water, and soil). Unfortunately, water obtained in this way is simply discharged into the underground, often at the ratio of 1:1, or more. That is why an exceptional attention must be paid in practice to water losses, especially as highly efficient methods are nowadays available for curbing such losses.

Also, in addition to using the most economical ways to operate the existing water supply facilities, this facility management stage also implies appropriate education and lifelong or continuous education of experts, proper organization of work, as well as all other activities that are needed for proper management, operation and maintenance of the water supply infrastructure.

(5) In addition to supervision and verification of proper realization of goals, measures and activities from preceding phases, one of them being environment monitoring, the last phase - monitoring and control - also includes collection and analysis of feedback and data that are entered into the existing data base to determined efficiency indicators and condition of the system, and to detect improvement possibility, and enable implementation of the new cycle of water supply management.

\section{Vision for the next decade}

One of important reasons preventing fuller implementation of the sustainability concept, and hence of the concept of sustainable water supply, is the current level of scientific advancement, i.e. the lack of scientific procedures that would enable us to fully cope with the ever increasing problems in this area.

Thus, present day water conditioning and waste water purification technologies are highly intensive from the standpoint of chemical impacts, use of energy, and operating requirements. This is why highly efficient, inexpensive and robust technologies, with minimum impact on our environment, should be developed [14, 23]. Significant developments and advances in the science and water treatment technology are now being enabled through discoveries in the field of nanoscience or nanotechnology.

Nanotechnology deals with the research, development and use of structures, devices and systems the size of which can be measured in atoms and molecules, i.e. it reaches up to $100[\mathrm{~nm}]\left(1[\mathrm{~nm}]=10^{-9}[\mathrm{~m}]\right)$. Thanks to their miniscule size nanostructures have some special properties such as high strength and hardness, chemical stability, thermal and electrical conductivity, etc. [28, 29].

Here the basic objective is to develop procedures enabling synthesis of materials at the atomic (nano)level, i.e. manipulation of individual atoms, and atom and molecule clusters, and their rearrangement into new (nano)structures (Figure 10.), and merger with bigger systems.
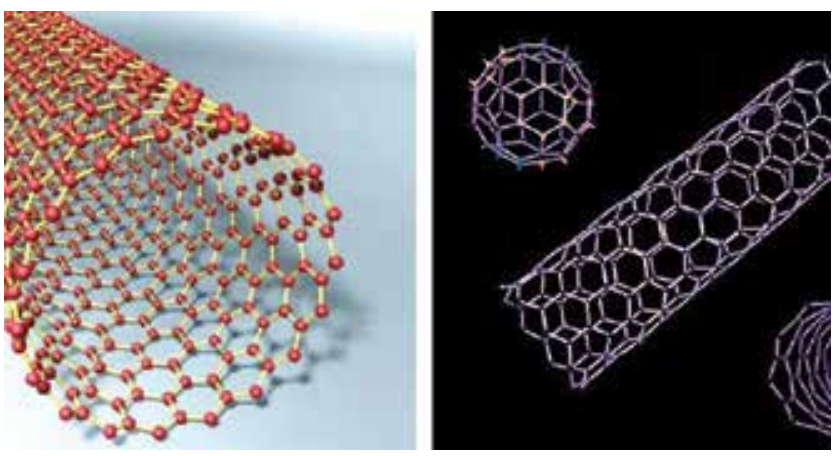

Figure 10. Nanostructure - carbon nanotubes

In the current situation characterized by demographic expansion, it is believed that highly efficient solutions to global challenges can be found, e.g. in the field of protection of water and other components of clean environment, in considerable reduction of energy consumption, in medicine, food production, preservation of biological diversity, use of mineral resources, abatement of climate changes, and development of new methods for conversion of renewable sources of energy, water treatment, etc. [1].

Nanotechnology also promises improvements in the sphere of sustainability as we will be using less water, less materials, less energy, and so less waste will be generated [30].

Over the past decade, a significant progress has been made in the development and use of nanotechnological solutions in the field of water treatment presenting minimum impact on natural environment. The most notable research is given in [31, 32, 33]:

- nanobiocides made of nanoparticles based on magnesium and silver that can deactivate bacteria from polluted water without creating toxic by-products;

- nanoadsorbents made of (a) nanoparticles, and (b) nanostructured materials, which remove heavy metals ( $\mathrm{Cr}, \mathrm{Cd}, \mathrm{Hg}, \mathrm{Zn}, \mathrm{As}, \mathrm{Cu})$ and dissolved organic substances (compounds) from polluted water; 
- $\quad$ nanostructured filters and filtration systems based on (a) nanoparticles, and (b) nanosilver and carbon nanotubes, which can inter alia remove bacteria and viruses from water;

- Zeolite nanocomposite low-pressure membranes for reverse osmosis, by which dissolved $\mathrm{Ca}, \mathrm{Mg}$ and $\mathrm{Na}$ salts (desalination), and dissolved organic substances, are removed from water.

Further application of nanotechnology-based solutions will greatly improve possibilities for achieving sustainability in the water supply sector, especially as it will not be necessary to build new or make significant improvements to the existing water supply infrastructure [6].

\section{Review of current situation and development of water supply in the Republic of Croatia}

The Republic of Croatia ranks among the countries abounding in water, as confirmed by the latest Report on environmental situation in the Republic of Croatia for the period from 2005 to 2008 [34] where it is indicated that an average quantity of water collected in the aforementioned period amounted to about $0.53\left[\mathrm{~km}^{3}\right.$ year $\left.{ }^{-1}\right]$, or to no more than about $0.5[\%]$ of the total renewable (surface and ground) waters, which are estimated at about $100\left[\mathrm{~km}^{3}\right.$ years $\left.{ }^{-1}\right]$, or about $25 \cdot 10^{3}\left[\mathrm{~m}^{3}\right.$ inhabitant ${ }^{-1}$ year $^{-1}$.

Out of the above mentioned average annual quantities of water collected, as many as $0.48\left(\mathrm{~km}^{3}\right.$ year $\left.{ }^{1}\right]$ is destined to public water supply with the following consumption structure: population $0.15\left[\mathrm{~km}^{3}\right.$ year $\left.{ }^{-1}\right]$ or $100\left[\right.$ inhabitant $\left.\mathrm{t}^{-1} \mathrm{~d}^{-1}\right]$, industry $0.08\left[\mathrm{~km}^{3}\right.$ year $\left.{ }^{-1}\right]$, sub-distributors $0.04\left[\mathrm{~km}^{3}\right.$ year $\left.{ }^{-1}\right]$ and water losses in water supply systems $0.21\left[\mathrm{~km}^{3}\right.$ year $\left.{ }^{-1}\right]$ or $44[\%]$.

Although the above data on the collected water to renewable (available) water ratio point to an exceptional abundance in water resources, it should be noted that the time (annual) and space distribution of water in the Republic of Croatia is irregular and unfavourable.

In addition, the quality of water is gradually deteriorating due to changes in environment caused by natural flooding and influence of human activity. It would therefore be significant to ensure a sustainable water management so as to be able to preserve our water resources for use by future generations. This especially concerns ground waters as almost 90 [\%] of water supply comes from ground water reserves.

For that reason, a number of documents relevant for the protection of water and water environments, as based on the General Water Directive [35], were prepared over the past period of intensive harmonisation with water regulations applied in the European Union. Some of these documents are: Sustainable Development Strategy of the Republic of Croatia [36], Water Management Strategy [37], Water Act [38], Byelaw on Limit Waste Water Emission Values [39], Ordinance on Standard Quality of Water [40], and Byelaw on Requirements for the Determination of Zones of Sanitary Protection of Water Sources [41].

The fundamental objective of all these documents and regulations is to provide for a systemic and continuous protection of water resources not only in terms of quality but in terms of quantity as well, which will eventually enable realization of the concept of sustainable water supply in the Republic of Croatia.

\section{Conclustion}

Former approach for resolving water supply problems under conditions of demographic expansion, strong growth of industrial production, and great increase in food production (irrigation), was based on continuous search for new sources of water, and on construction of big water supply systems which are very intensive as to the use of space, infrastructure, energy, chemical substances, technology, and operation, with highly negative impacts on our environment.

The expected increase in water consumption due to population growth will bring about additional pressure on water resources. Thus the fundamental feature of the present day water supply is its unsustainability in practically all segments, which is why comprehensive, rapid, and efficient action and changes are needed in order to solve water supply problems and ensure orientation toward the sustainable water supply. Water supply problems may be solved by increasing water supply and reducing water demand. A highly efficient way for increasing the available water supply, otherwise inaccessible from the natural hydrological cycle, is the recycling and reuse of waste water. This is, in addition to ensuring continuous supply of water, one of the most efficient ways for protecting the environment. The savings in water use should primarily originate from the changes in our attitude and relationship toward water and water supply. These savings can be made at all household water appliances and fixtures, and in industry. Furthermore, water supply systems must be managed in an integrated way if a sustainable water supply situation is to be attained. At that, proper planning is a very significant first step of high significance for the overall success of the water supply system management.

A significant progress toward sustainable water supply is presently enabled through discoveries in the field of nanotechnology, which also promises improvements in the sphere of sustainability as we will be using less water, less material, less energy and, in turn, less waste will be generated. Further application of nanotechnology-based solutions will greatly improve possibilities for achieving sustainability in the water supply sector, especially as such solutions are not likely to require substantial construction of new water supply systems, or upgrade of the existing facilities. 


\section{REFERENCES}

[1] Diallo, M., Brinker, C. J.: Nanotechnology for Sustainability: Environment, Water, Food, Minerals, and Climate, www.usf.gov/ crssprgm/nano/reports/nano2/chapter0.5pdf, 2010, 157-187.

[2] Raven, P. H., Berg, L.R., Hassenzahl, D. M.: Environment, 7th edn, John Wiley and Sons, New York, 2010.

[3] Hurley, C., North, J.: Sustainable Water Manegement, www. americainfra.com, 2010.

[4] Montgomery, M. A., Elimelech, M.: Water and sanitation in developing countries: including health in the equation, Environmental Science and Technology, 41, 2007, 17-24.

[5] Ishaku, H. T., et al.: Planning for Sustainable Water Supply through Partnership Approach in Wukari Town, Taraba State of Nigeria, Journal of Water Resource and Protection, 2, 2010, 916922.

[6] Gleick, P. H., at al.: California Water 2020: A Sustainable Vision, www.pacist.org/reports/california_water_2020/summary. htm, 2005

[7] Brundtland, H.: Towards sustainable development (Chapter 2 in A/42/427. Our common future: Report of the World Commission on Environment and Development, New York, 1987, (www.undocuments.net/ocf-02.htm).

[8] Rapport, D. J.: Sustainable science: An ecohealth perspective, Sustainability Science 2, 2007, 77-84.

[9] International Union for Conservation of Nature (IUCN): Ecotourism, special issue, Parks 2(3), 1991, 2-20.

[10] Rockström, J., et al.: A safe operating space for humanity, Nature 461, 2009, 472-475.

[11] Bonnaci, O.: Analiza nizova srednjih godišnjih temperatura zraka u Hrvatskoj, Gradevinar 62, (2010.) 9, 781-791.

[12] Sara, J., Katz, T.: Making Rural Water Supply Sustainable, World Bank (WB), Water and Sanitation Program, Washington, D. C., 2004.

[13] Harley, J., Mercer, D.: Sustainable water systems and household practicies, www.mams.rmit.edu.au/ib1nma3bs6rk.pdf, 2006.

[14] Shannon, M. A., et al.: Science and technology for water purification in the coming decades, Nature 452, 2008, 301-310.

[15] Crichlow, M.: Water Demand, www.yyy.rsmas.miami.edu/IAl/ Inst2001/lectures/crichlow_jul19/crichlow_t_jul19b.pdf, 2001.

[16] Savic, D. A., Walters, G.A.: Evolving sustainable water networks, Hydrological Sciences, 42(4), 1997, 549-564.

[17] World Bank (WB): The Challenge of Reducing Non-Revenue Water in Developing Countries, Water Supply and Sanitation Sector Board Discussion Paper Series, Paper No. 8, Washington, D. C. 2006.

[18] Richter, B. D., et al.: Ecologically Sustainable Water Management Managing River Flows for Ecological Integrity, Ecological Applications, 131(1), 2003, 206-224.

[19] Miller, G. T.: Living in the Environment, 15th edn, Thomson Brook/Cole, Belmont, 2007.

[20] Jacobs, K., Maguire, R.: Toward a Sustainable Water Supply: Tools and Opportunities, www.ag.arizona.edu/AZWATER/ publications/townhall/Chapter10.pdf, 2004, 141-146.
[21] Aravinthan, V.: Reclaimed Wastewater as a Resource for SustainableWater Management, Managing Resources for a Sustainable Future, University of Southern Queensland, 2005, $1-11$.

[22] www.watereducation.org/userfiles/Yannotta.pdf, 2010.

[23] Elimelech, M.: Science and Technology for Sustainable Water Supply, Journal of Membrane Science, 298 (2007), 136-146.

[24] Gray, J.: Water and Sustainable Design, www.sustainablebuild. co.uk/SustainableDesignWater.html, 2010.

[25] Karleuša, B., Beraković, B., Rajčić, V.: Ekspertni sustavi za ocjenu uspješnosti planiranja u gospodarenju vodama, Gradevinar 64 (2010) 1, 1-11.

[26] Vuković, Ž., Halkijević, l.: Globalni izazovi klimatskih promjena i vodnogospodarska planiranja, 5. hrvatska konferencija o vodama, Opatija, 2011, 89-98.

[27] Carpenter, T. G. (ed.): Environment, construction and sustainable development, Vol. 1-2, John Wiley and Sons, New York, 2001.

[28] Schulte, J. (ed.): Nanotechnology: Global Strategies, Industry Trends and Applications, John Wiley and Sons, New York, 2005.

[29] Jakobović, Z. (ur.): Tehnički leksikon, Leksikografski zavod Miroslav Krleža, Zagreb, 2007

[30] Roco, M. C.: From vision to the implementation of the U. S. National Nanotechnology Initiative, Journal of Nanoparticle Research, 3(1), 2001, 5-11.

[31] Savage, N., Diallo, M.: Nanomaterials and water purification: Opportunities and challenges, Journal of Nanoparticle Research, 7, 2005, 331-342.

[32] Hillie, T., Munshinghe, M., Hlope, M., Deraniyagala, Y.: Nanotechnology, water and development, www.merid.org/ nano/waterpaper.pdf, 2006

[33] Shannon, M. A.: Net energy and clean water from wastewater, ARPA-E Workshop, www.arpae.energy.gov/ConferenceEvents/ PastWorkshops/Wastewater.aspx., 2010.

[34] Izvješče o stanju okoliša u Republici Hrvatskoj za razdoblje od 2005. do 2008. godine, Vlada Republike Hrvatske, Zagreb, 2011.

[35] Directive 2000/60/EC of the European Parliament and of the Council of 23 October 2000 Establishing a Framework for Community Action in the Field of Water Policy. Official Journal L 327, 22. 12. 2000 P.0001.

[36] Strategija održivog razvitka Republike Hrvatske, NN 30/09.

[37] Strategija upravljanja vodama, NN 91/08.

[38] Zakon o vodama, NN 153/09, 130/11.

[39] Pravilnik o graničnim vrijednostima emisija otpadnih voda, NN $87 / 10$.

[40] Uredba o standardu kakvoće voda, NN 89/10.

[41] Pravilnik o uvjetima za utvrđivanje zona sanitarne zaštite izvorišta, NN 66/11. 